Uniwersytet Jana Kochanowskiego w Kielcach

jan.zych@cyberman.com.pl

CEZARY FóRMANIAK

Akademia Marynarki Wojennej w Gdyni

\title{
APPLication OF KNOWLEDGE CONVERSION MODEL IN IMPROVING SAFETY ANALYSTS COMPETENCES
}

\author{
ZASTOSOWANIE MODELU KONWERSJI \\ WIEDZY W DOSKONALENIU KOMPETENCJI \\ ANALITYKÓW BEZPIECZEŃSTWA
}

\begin{abstract}
The guiding principle of the article is: one of the most difficult to shape the competences of modern security analysts, is the ability to overcome the existing thought patterns and replace them with new views, adequate to current and future threats and challenges. The selected elements of research on the utilitarian aspect of the use of knowledge conversion mechanisms presented here relate to the sphere of security, including the protection of life, health, property and the environment. The article describes the possibilities of using the Ikujiro Nonaka and Hirotaka Takeuchi conversion model, and the narrative is placed in the area of security, exposing the mechanisms of learning from experience and the transformation of hidden knowledge into explicit knowledge.

\section{STRESZCZENIE}

Teza przewodnia artykułu brzmi: jedną z najtrudniejszych do kształtowania kompetencji współczesnych analityków bezpieczeństwa jest umiejętność przełamywania zastanych schematów myślowych i zastępowania ich nowymi poglądami, adekwatnymi do aktualnych i przyszłych zagrożeń oraz wyzwań. Prezentowane tu wybrane elementy badań nad utylitarnym aspektem stosowania mechanizmów konwersji wiedzy dotyczą sfery bezpieczeństwa, w tym ochrony życia, zdrowia, mienia i środowiska. W artykule opisano możliwości zastosowania modelu konwersji wiedzy Ikujira Nonaki i Hirotaki Takeuchiego, a narrację umieszczono w obszarze bezpieczeństwa, eksponując mechanizmy uczenia się na podstawie doświadczeń oraz transformacji wiedzy ukrytej w wiedzę jawną.
\end{abstract}


KEYWORDS: open knowledge, hidden knowledge, knowledge conversion, lessons learned, Nonaka and Takeuchi

SŁOWA KLUCzowe: wiedza jawna, wiedza ukryta, konwersja wiedzy, lessons learned, Ikujiro Nonaka, Hirotaka Takeuchi

\section{WPROWADZENIE}

Współczesne zarządzanie bezpieczeństwem opiera się na informacjach dostarczanych przez analityków. Analizie poddawane są dane zarówno ilościowe, jak i jakościowe. Szczególnego znaczenia nabiera wyciąganie wniosków z doświadczeń. Aby uczyć się na doświadczeniach, kluczowe staje się przechwytywanie wiedzy ukrytej i sprowadzenie jej do postaci jawnej. Wiedza jawna zazwyczaj jest skodyfikowana, względnie łatwo ją definiować. Wiedzę tego rodzaju można przyswoić poprzez uczenie się na doświadczeniach i może być ona przedmiotem wnioskowania realizowanego przez analityków (Flizikowski, Zych, Hołubowicz, 2012, s. 230-237). Wyzwanie dla nauki stanowi wciąż wiedza ukryta, którą trudno zidentyfikować.

Takie dwa rodzaje wiedzy były przedmiotem badań japońskich naukowców: Ikujira Nonaki i Hirotaki Takeuchiego. Wypracowali oni mechanizmy ekstrakcji i konwersji tej szczególnej wiedzy. Chodzi o przetworzenie tzw. wiedzy ukrytej (ang. tacit knowledge) na tzw. wiedzę jawną (ang. explicit knowledge) (Jamielniak, Koźmiński, 2008, s. 26). Wiedza ukryta ma specyficzne cechy:

- jest nieskodyfikowana (nie jest spisana),

- wynika z dzielenia się tzw. życiowymi doświadczeniami.

Obie te cechy trudno zidentyfikować i trudno zdefiniować, a tym bardziej transponować na wiedzę ustrukturalizowaną, w taki sposób, aby świadomie jej używać i maksymalizować efekt synergii.

W artykule eksponowany jest potencjał tkwiący w stosowaniu metody konwersji wiedzy wypracowanej przez Ikujira Nonakę i Hirotakę Takeuchiego (Nonaka, Takeuchi, 2000, s. 40). W opinii autorów ważne jest, aby bazując na przeszłości, trafnie ekstrapolować stany przyszłe znajdujące się poza standardowym postępowaniem, dla którego dysponujemy w danym momencie wystarczającym materiałem faktograficznym. Procesy ekstrakcji i konwersji realizowane są poprzez dopasowanie do istniejących już doświadczeń (zwią- 
zanych z faktami czy odrobionymi już lekcjami z minionych zdarzeń). Mechanizmy wypracowane przez japońskich naukowców mają niszową cechę wyzwalania kreatywnego myślenia, korygowanego bazą wiedzy pozytywnie zweryfikowanej w antycypowaniu stanów przyszłych.

W opinii autorów największą sztuką jest umiejętność obalania zastanych schematów myślowych i zastępowania ich nowymi, adekwatnymi do realiów. Teza przewodnia artykułu brzmi: jedną z najtrudniejszych do kształtowania kompetencji współczesnych analityków bezpieczeństwa jest umiejętność przełamywania zastanych schematów myślowych i zastępowania ich nowymi poglądami, adekwatnymi do aktualnych i przyszłych zagrożeń oraz wyzwań.

\section{EDUKACJA ANALITYKÓW BEZPIECZEŃSTWA}

W wyniku ataku na World Trade Center jedna z firm (Cantor Fitzgerald) straciła siedmiuset z tysiąca pracowników. Pracownicy, którzy przeżyli, stanęli wobec alternatywy: albo wypracują model odrodzenia firmy, adaptując się do nowych okoliczności, albo firma zbankrutuje. Podjęli wysiłek, który wydawał się skazany na porażkę. Wprawdzie cała dokumentacja przetrwała na dyskach zewnętrznych, ale nie przeżył nikt, kto znał hasła dostępu do serwerów. I co się wydarzyło? Zaczęli odkrywać wiedzę, która do tej pory była ukryta. Zaczęli przypominać sobie wszystko, co wiedzieli o swoich kolegach: w czym się specjalizowali, jakie mieli przyzwyczajenia, nawyki, jak rozwiązywali problemy, jakie relacje łączyły poszczególnych pracowników, jakie mieli zainteresowania, co było ich pasją. Podjęto udaną próbę sparametryzowania zdarzeń i swoich obserwacji (rysunek 1): kiedy, kto, gdzie, co, jak?

Rysunek 1.

Mechanizm ekstrakcji i konwersji wiedzy dla obiektu krytycznego (wariant)
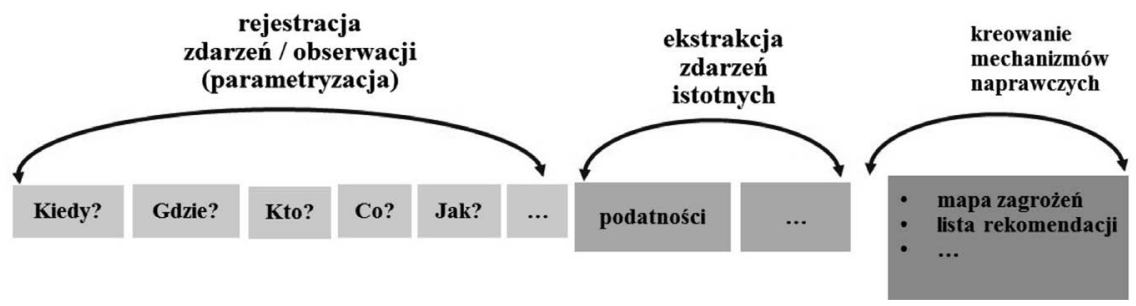

Źródło: opracowanie własne. 
Wyekstrahowano zdarzenia istotne i wypracowano rekomendacje będące propozycjami działań naprawczych. Stosując mechanizm ekstrakcji i konwersji wiedzy, zdołano odtworzyć najpierw hasła, a później knowhow (konkretną wiedzę techniczną z danej dziedziny, umiejętność wykonania lub wyprodukowania czegoś, kompetencję, biegłość) stanowiący istotę przewagi konkurencyjnej, jakim charakteryzowała się firma Cantor Fitzgerald.

Ten przykład, oparty na autentycznych wydarzeniach, egzemplifikuje mechanizm pozyskiwania wiedzy nieskodyfikowanej. Dla opisywanej firmy to szczególnie dramatyczny kontekst, który uzmysławia, że sposobem na radzenie sobie $\mathrm{z}$ problemami w zakresie zarządzania bezpieczeństwem jest konwersja wiedzy. Przetrwanie organizacji zależało tutaj od umiejętności zebrania rozproszonej i ukrytej wiedzy, będącej pochodną rutynowych często działań, które scalają organizację niezależnie od skali (Watts, 2013, s. 9-14).

Autorzy artykułu zaadaptowali mechanizmy wypracowane przez Nonakę i Takeuchiego do praktyki wykorzystania doświadczeń w obszarze bezpieczeństwa, do identyfikacji nowych zagrożeń. Takie podejście rozszerza możliwości analityczne i wzmacnia kompetencje analityków bezpieczeństwa.

Innymi słowy, ze zbioru wszelkich zdarzeń wyodrębniono podzbiór zdarzeń istotnych względem przyjętego kryterium (istotności dla analizowanego problemu ochrony obiektu wrażliwego na zagrożenia), aby następnie zidentyfikować i badać przyszłe korelacje, koincydencje, związki przyczynowo-skutkowe - ilościowe i jakościowe, które mają służyć usprawnianiu organizacji (Jóźwiak, Laskowski, Zych, 2005, s. 989-994). Usprawnienie służyło zapewnieniu odpowiedniego poziomu bezpieczeństwa poprzez:

- lepszą niż dotychczas detekcję zagrożeń, przy orientacji na stany i procesy przyszłe;

- skrócenie cyklu decyzyjnego;

- optymalizację wydatków na ochronę ochrony obiektu wrażliwego na zagrożenia. 


\section{WYBRANE ASPEKTY ZREALIZOWANYCH BADAŃ WEASNYCH}

Dla zobrazowania możliwości wykorzystania modelu konwersji wiedzy do podnoszenia kompetencji analitycznych analityków bezpieczeństwa zostanie zaprezentowany w syntetycznej formule wybrany fragment własnych badań w tym zakresie. W trakcie warsztatów kompetencyjnych prowadzonych $\mathrm{z}$ kandydatami na analityków bezpieczeństwa realizowano badania nad możliwościami zastosowania konwersji wiedzy do identyfikowania nowych zagrożeń. Warsztaty realizowano w grupach. W pierwszym etapie badania uczestnicy warsztatów w poszczególnych grupach byli zapoznawani z teoretycznymi aspektami modelu konwersji wiedzy. Następnie uczestnicy poszczególnych grup modelowali wybraną organizację, sprowadzając obiekt rzeczywisty do opisu jego głównych funkcjonalności.

Socjalizacja: aby zbudować model organizacji, uczestnicy poszczególnych grup musieli wykonać indywidulną pracę analityczną, polegającą na możliwie jak najszerszym zapoznaniu się $\mathrm{z}$ informacjami na temat organizacji (materiały internetowe, publikacje zwarte, czasopisma branżowe). To umożliwiało uczestnikom poczynić nowe spostrzeżenia i doświadczyć nowych skojarzeń na temat analizowanego obiektu rzeczywistego.

Eksternalizacja: realizowano burzę mózgów między grupami, w wyniku której nanoszone były korekty do wypracowanych już modeli opisowych. Model opisowy był następnie sprowadzany do bardziej sformalizowanej postaci, z wykorzystaniem zaprojektowanego do tego celu narzędzia (Fórmaniak, 2015, s. 36-52) - arkusza diagnostycznego.

Kombinacja: na wykonanych modelach realizowano projektowanie zagrożeń dla głównych funkcjonalności obiektu rzeczywistego. Stawiano przy tym na kreatywność i stosowano metody aktywizujące do snucia wizji - metody należące do zbioru metod badań nad przyszłością, znanych jako „foresight”. Poszczególni uczestnicy badania projektowali zagrożenia na modelach zbudowanych nie przez siebie, a przez innych uczestników. W ten sposób wspólna wiedza jawna stawała się źródłem inspiracji do projektowania nowych propozycji rozwiązań - tutaj: propozycji sposobów ochrony przed nowymi zagrożeniami. Te propozycje, jako rekomendacje, sprowadzano do postaci dokumentu instrukcyjnego i podawano pod dyskusję nad jakością 
wytworzonej dokumentacji. Wytworzoną dokumentację poddawano następnie analizie eksperckiej.

Internalizacja: uczestnicy warsztatów w grupach zapoznawali się ze skodyfikowaną wiedzą sprowadzoną do postaci instrukcyjnej, a następnie wymieniali poglądy na temat zamodelowanej organizacji. Skupiono się na aspekcie zarządzania bezpieczeństwem, mając na względzie nowe zagrożenia, najpierw zaprojektowane, a następnie skonkretyzowane w trakcie kolejnych etapów konwersji wiedzy. Taka wymiana poglądów zamyka jedną pełną iterację w konwersji wiedzy. Zinternalizowana wiedza podlega następnie socjalizacji i kolejnej próbie wykonania modelu organizacji, czyli eksternalizowana jest kolejny raz wiedza ukryta, ale zmodyfikowana już o nabyte doświadczenie.

\section{Problemy edukacy Je}

Aby skutecznie identyfikować w praktyce nowe zagrożenia, wymagane jest kształcenie przyszłych analityków bezpieczeństwa w zakresie uczenia się na podstwie doświadczeń, z uwzględnieniem mechanizmów konwersji wiedzy ukrytej. Z analizy ofert edukacyjnych dostępnych w uczelniach wyższych w Polsce (Zych i in., 2016, s. 22-29) kształcących w obszarze nauk o bezpieczeństwie na kierunkach związanych $\mathrm{z}$ bezpieczeństwem wewnętrznym lub narodowym wynika, że problematyka uczenia się na doświadczeniach w zasadzie nie jest obecna $\mathrm{w}$ tych ofertach. $\mathrm{Z}$ tego powodu wątek ten wydaje się szczególnie ważny i wart wyeksponowania.

Termin „analityk” pochodzi z języka greckiego. Termin „analiza” (łac.

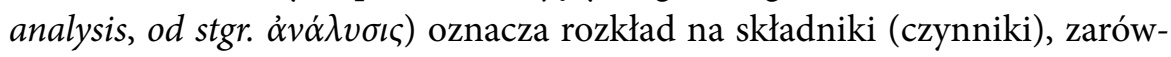
no w znaczeniu materialnym, jak i niematerialnym; chodzi o wyodrębnienie charakterystycznych cech, właściwości, składników badanego przedmiotu lub zjawiska. Encyklopedia PWN (1995, s. 32) definiuje pojęcie „analityk” na wiele uzupełniających się sposobów. Jedna $z$ definicji oddaje istotę tego pojęcia w sformułowaniu: ,jest to specjalista zajmujący się analizą danych i prognozowaniem".

Nie oznacza to oczywiście, że analityk posługuje się tylko i wyłącznie analizą. Najczęściej stosowane są metody rozumowania: analiza, synteza, indukcja, dedukcja i analogia. Analityk w praktyce stosuje szerokie spektrum metod i technik (tabela 1 na następnej stronie). 
Tabela 1.

Najczęściej stosowane uniwersalne metody rozumowania

\begin{tabular}{|c|c|c|}
\hline Lp. & Nazwa metody & Syntetyczna charakterystyka metody \\
\hline 1. & Abstrahowanie & Zorientowane jest na pomijanie nieistotnych elementów. \\
\hline 2. & Analiza & $\begin{array}{l}\text { Jest to proces myślowy polegający na rozłożeniu pewnej całości na } \\
\text { jej części składowe i rozpatrywanie każdej z nich osobno. Analiza } \\
\text { ma na celu wyodrębnienie cech, właściwości, składników badanego } \\
\text { przedmiotu lub zjawiska (Apanowicz, 2002, s. 24). }\end{array}$ \\
\hline 3. & Analogia & $\begin{array}{l}\text { Metoda ta oparta jest na rozumowaniu polegającym na przenosze- } \\
\text { niu twierdzeń dotyczących jednego zjawiska na inne, na podstawie } \\
\text { zachodzących między nimi podobieństw. Analogia jest przypad- } \\
\text { kiem „wnioskowania pośredniego” mieszczącego się między in- } \\
\text { dukcją i dedukcją. }\end{array}$ \\
\hline 4. & Dedukcja & $\begin{array}{l}\text { Polega na rozumowym „przechodzeniu” od ogółu do szczegółu, } \\
\text { czyli jest to taki proces myślowy, w którym na podstawie wiadomo- } \\
\text { ści o całości, wnioskujemy o niektórych jej częściach składowych } \\
\text { (elementach, przedmiotach) (Apanowicz, 2002, s. 25-26). }\end{array}$ \\
\hline 5. & Indukcja & $\begin{array}{l}\text { Polega na wyprowadzeniu wniosków z przesłanek będących po- } \\
\text { jedynczymi przypadkami. Indukcja jest procesem wnioskowania, } \\
\text { w którym na podstawie obserwacji jednostkowych faktów formu- } \\
\text { łowane są uogólnienia (Apanowicz, 2002, s. 25-26); metoda ta jest } \\
\text { obarczona dużym ryzykiem nieprawdziwości wniosków, co jest } \\
\text { wadą, natomiast zaletą indukcji jest jej przydatność do projekto- } \\
\text { wania przyszłości. }\end{array}$ \\
\hline 6. & Konkretyzacja & $\begin{array}{l}\text { To ścisłe określenie czegoś, połączone zwykle z działaniem prak- } \\
\text { tycznym. }\end{array}$ \\
\hline 7. & Redukcja & Rozumowanie ukierunkowane na pozbycie się zbędnych elementów. \\
\hline 8. & Synteza & $\begin{array}{l}\text { Jest to rozumowe łączenie wyodrębnionych czynników, elementów, } \\
\text { części, cech, relacji danego problemu, procesu, struktury lub orga- } \\
\text { nizacji (Apanowicz, 2002, s. 25, 74, 112). }\end{array}$ \\
\hline 9. & Weryfikacja & $\begin{array}{l}\text { Sprawdzenie, czynność intelektualna zmierzająca do rozstrzygnię- } \\
\text { cia prawdziwości danego zdania. }\end{array}$ \\
\hline
\end{tabular}

Źródło: opracowanie własne.

Wymienione w tabeli 1 uniwersalne metody rozumowania występują zazwyczaj pod postacią nazw własnych, a po wyposażeniu ich w zestaw narzędzi i technik ich użycia obecne są jako metody naukowe, czego przykłady podano w tabeli 2 na następnej stronie. 
Tabela 2.

Najczęściej stosowane uniwersalne metody naukowe

\begin{tabular}{|c|c|c|}
\hline Lp. & Nazwa metody & Syntetyczna charakterystyka metody \\
\hline 1. & $\begin{array}{l}\text { Metoda } \\
\text { monograficzna } \\
\text { (Apanowicz, 2005, } \\
\text { s. } 67)\end{array}$ & $\begin{array}{l}\text { Metoda monograficzna polega na szczegółowym badaniu } \\
\text { konkretnego (indywidualnego) przypadku, to znaczy jed- } \\
\text { nostki statystycznej, którą może być jakaś instytucja, zakład, } \\
\text { warsztat, grupa społeczna (określona zbiorowość lub popula- } \\
\text { cja), uwzględniającym przede wszystkim informacje w formie } \\
\text { jakościowo-opisowej. }\end{array}$ \\
\hline 2. & $\begin{array}{l}\text { Metoda badania } \\
\text { dokumentów } \\
\text { (Koernik, 2006, } \\
\text { s. 16) }\end{array}$ & $\begin{array}{l}\text { Metoda badania dokumentów polega na gromadzeniu, selekcji, } \\
\text { opisie i naukowej interpretacji zawartych w nich interesujących } \\
\text { nas faktów. Jest to analiza polegająca na wyodrębnieniu, a następ- } \\
\text { nie rozłożeniu na części i interpretacji elementów składowych } \\
\text { konkretnego zjawiska lub procesu rzeczywistego działania. }\end{array}$ \\
\hline 3. & $\begin{array}{l}\text { Metoda projektowa } \\
\text { (Fórmaniak } \\
\text { na podstawie } \\
\text { Borodako, 2009, } \\
\text { s. 25-29) }\end{array}$ & $\begin{array}{l}\text { To metoda antycypacji przyszłości polegająca na wypraco- } \\
\text { wywaniu i poddawaniu badaniom projektów przyszłych sta- } \\
\text { nów, zdarzeń, procesów na podstawie zgromadzonej wiedzy, } \\
\text { najczęściej o charakterze jakościowym, przy deficycie wiedzy } \\
\text { o charakterze ilościowym oraz przy wykorzystaniu doświad- } \\
\text { czenia eksperckiego. }\end{array}$ \\
\hline 4. & $\begin{array}{l}\text { Metoda studium } \\
\text { przypadku } \\
\text { (Zych, Fórmaniak, } \\
\text { 2016, s. 11-20) }\end{array}$ & $\begin{array}{l}\text { To działanie polegające na analizie pojedynczego konkretne- } \\
\text { go przypadku, który miał już miejsce wraz z dokładną analizą } \\
\text { okoliczności rozpatrywanego przypadku lub może to być an- } \\
\text { tycypacyjne rozpatrywanie przyszłości; powszechnie stosuje } \\
\text { się też alternatywne nazwy dla studium przypadku, tj. analiza } \\
\text { przypadku oraz anglojęzyczne określanie - case study. }\end{array}$ \\
\hline 5. & $\begin{array}{c}\text { Metoda sytuacyjna } \\
\text { (metoda } \\
\text { przypadków) } \\
(\text { Zych, 2013, s. 14, 33) }\end{array}$ & $\begin{array}{l}\text { To metoda polegająca na dokładnym rozpatrzeniu szczegól- } \\
\text { nego przypadku tak skonstruowanego, żeby był on typowy dla } \\
\text { rozpatrywanej klasy zdarzeń. Istotą tej metody jest wyrabianie } \\
\text { umiejętności wszechstronnego analizowania problemów skła- } \\
\text { dających się na tzw. sytuację trudną, a także podejmowania na } \\
\text { tej podstawie odpowiednich decyzji oraz wskazywania prze- } \\
\text { widywanych następstw poczynań zgodnych z tymi decyzjami. } \\
\text { Metoda ma charakter prospektywny. }\end{array}$ \\
\hline 6. & $\begin{array}{l}\text { Metoda symulacji } \\
\text { komputerowej } \\
\text { (Zych, 2002, } \\
\text { s. 16-102) }\end{array}$ & $\begin{array}{l}\text { To wykorzystanie modelu matematycznego zapisanego w po- } \\
\text { staci programu komputerowego do analizy procesów sto- } \\
\text { chastycznych lub deterministycznych, szczególnie przydatne } \\
\text { w sytuacjach, gdy prowadzenie eksperymentów w warunkach } \\
\text { realnych zagrażałoby życiu, zdrowiu, mieniu lub środowisku } \\
\text { lub występowałyby ograniczenia natury humanitarnej, praw- } \\
\text { nej, ekonomicznej, politycznej. }\end{array}$ \\
\hline
\end{tabular}

Źródło: opracowanie własne. 


\section{Przeseanki KSZTA CENIA ANALITYKóW BEZPIECZEŃSTWA NA BAZIE MODELU KONWERSJI WIEDZY}

Model Nonaki i Takeuchiego (rysunek 2) osadzony jest w holistycznym modelu tworzenia wiedzy. Istnieją dwa rodzaje wiedzy: jawna, zawarta w instrukcjach i procedurach oraz niejawna (inaczej: ukryta), którą można posiąść tylko przez bezpośrednie doświadczenie - uczestnictwo bierne lub czynne w zdarzeniach, ale też dzięki doświadczeniu pośredniemu - poprzez metafory i analogie (tzw. wiedza z ust do ust). Nurt proamerykański eksponuje wiedzę jawną, skodyfikowaną. Wspomniani naukowcy japońscy koncentrują się na wiedzy ukrytej, którą uważają za kluczową do osiągania sukcesów. Dla Europejczyków wydaje się to kontrowersyjne, jednak model Nonaki i Takeuchiego został pozytywnie zweryfikowany przez świat nauki. Być może sukces Japończyków wynika z innej kultury mentalnej zakorzenionej w buddyzmie i cechach języka japońskiego lub filozofii zen, w której eksponuje się jedność człowieka z naturą, ciała z umysłem i świadomością. W artykule pominięto wyjaśnianie przejścia od filozofii greckiej i buddyzmu zen do klasycznych ekonomistów, współczesnych guru zarządzania. Liczna literatura na ten temat podaje wiele przykładów ilustrujących teorię tworzenia wiedzy organizacyjnej ze studiów przypadków. Poza wspomnianą we wstępie Cantor Fitzgerald, wiele firm, takich jak Honda, Canon, Matsushita, NEC, Nissan, 3M, GE, US Marines, wykorzystuje model uczenia się a podstawie doświadczeń i ekstrakcję wiedzy ukrytej. Na przykład firma Matsushita klarownie pokazuje, jak milcząca wiedza (jest to kolejna alternatywa dla nazwy „wiedza ukryta”) może być przekształcana do lepszego poznania i rozumienia rzeczywistości. A przecież właściwe zdiagnozowanie problemu pozwala zwiększać efektywność działań naprawczych. Wytwarzanie wiedzy wg Nonaki i Takeuchiego jest najlepsze, gdy tzw. kultura korporacyjna wyrażana jest przede wszystkim przez menedżerów niskiego i średniego poziomu, wytwarzając w ten sposób pomost między ideałami ścisłego kierownictwa a często chaotycznymi realiach codziennej, mozolnej pracy, w której trzeba podejmować tysiące mikrodecyzji. 
Rysunek 2.

Iteracyjny proces tworzenia wiedzy wg Nonaki i Takeuchiego

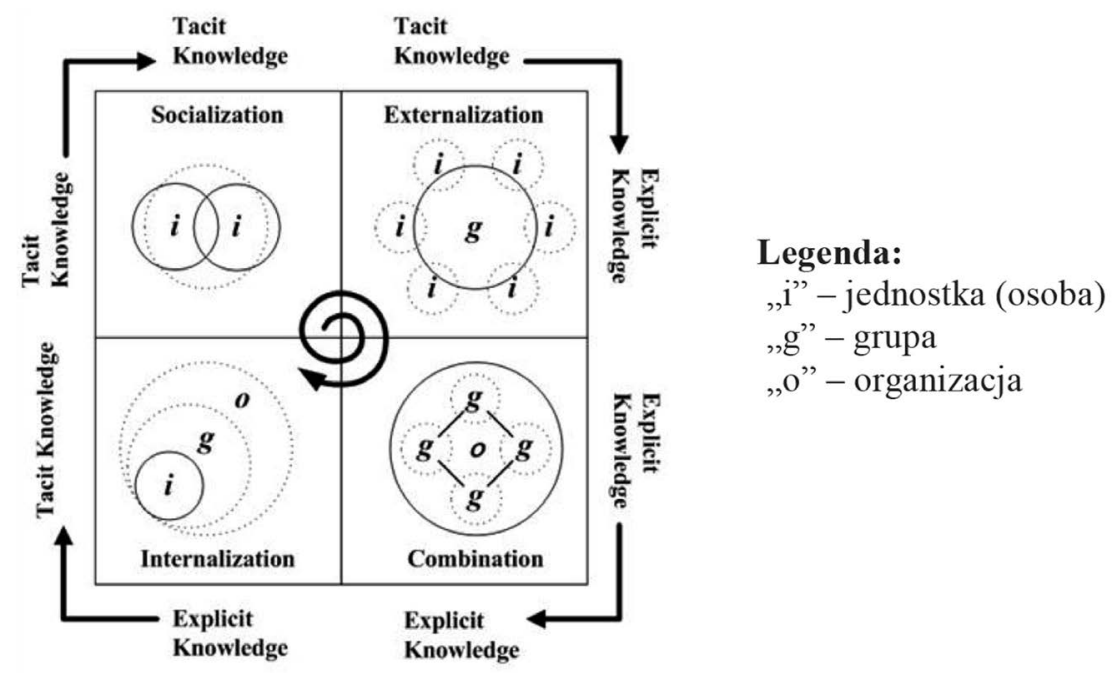

Źródło: http://www.comindwork.com/weekly/2017-03-27/productivity/seci-model-ofknowledge-dimensions-ikujiro-nonaka (dostęp: 10.08.2018).

Zamiarem Nonaki i Takeuchiego było wypracowanie modelu wytworzenia nowej wiedzy (rysunek 3), która staje się kluczem do utrzymania wysokiego poziomu bezpieczeństwa czy przewagi konkurencyjnej teraz lub w przyszłości, ponieważ w konkurencyjnym środowisku preferencje i oczekiwania obywateli zmieniają się nieustannie.

Unikatowa wiedza nieprzekazana czy też nieskodyfikowana po prostu zanika. Negatywnym przykładem są doświadczenia zebrane przez sztaby organizacyjne Mistrzostw Europy w piłce nożnej, jakie odbyły się w 2012 r. w Polsce i na Ukrainie. Know-how zdobyty w tej materii nie został w zasadzie nigdzie kompleksowo skodyfikowany czy zarchiwizowany. Niestety wiedza ukryta podlega z czasem erozji. Obecnie prawdopodobnie pamięć organizacyjna dotycząca tego przedsięwzięcia ulotniła się. Istotne jest więc, aby tworzyć wiedzę w sposób ciągły i bez zbędnej inercji ją operacjonalizować. Być może przeszczepienie na grunt naukowy metod konwersji wiedzy dla potrzeb praktyki bezpieczeństwa (np. zarządzanie kryzysowe, kształcenie analityków i menedżerów bezpieczeństwa) jest tylko kwestią czasu. 
Można przytaczać przykłady rażąco niewłaściwych zachowań wśród analityków bezpieczeństwa, koordynatorów akcji ratowniczych czy specjalistów ds. bezpieczeństwa itp., w przypadku których łatwo dostrzegalny jest brak zdolności do wydostania się z ciasnych gorsetów myślowych, co powoduje, iż narażane są życie lub zdrowie innych osób, w tym podległego tym osobom personelu. Funkcjonariusz danej służby znajdujący się w sytuacji realnego zagrożenia wykonując konkretne zadanie lub misję, w zasadzie nie ma wyjścia. Chcąc wyjść z niebezpiecznej sytuacji bez szwanku, musi szybko dostosować się do prawdziwego obrazu rzeczywistości. Błędne hipotezy lub założenia wstępne zweryfikuje przeciwnik, w tym także ten rozumiany jako stan natury.

Rysunek 3.

Proces tworzenia nowej wiedzy indywidualnej, grupowej i organizacyjnej wg Nonaki i Takeuchiego

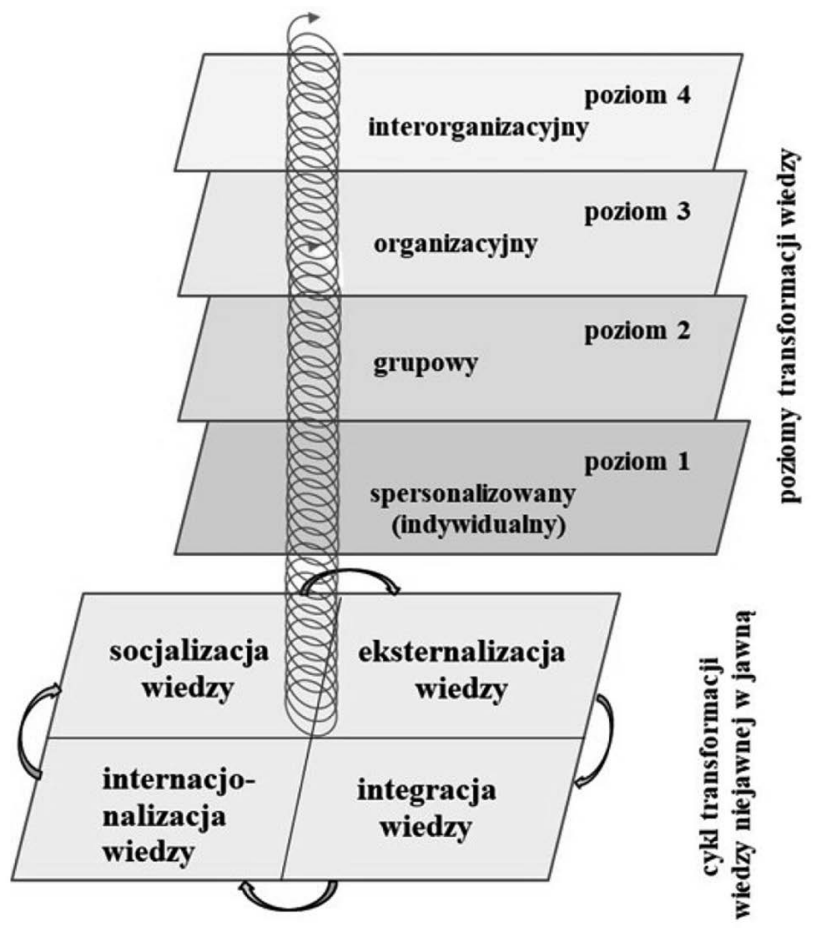

Źródło: opracowano własne na podstawie www.knowledge-management-tools.net, http:// www.knowledge-management-tools.net/knowledge-conversion.html (dostęp: 10.03.2018). 
Źle przygotowani zarządzający bezpieczeństwem, błędnie wyszkoleni koordynatorzy akcji, niekompetentne osoby funkcyjne, w tym politycy, zazwyczaj bezwiednie i naiwnie brną ścieżką indukcjonizmu, rozumianego przez nich jako projekcja ich „pobożnych” życzeń, przypodobania się elektoratowi, „grania pod publikę” lub wyznawania jakiejś pokrętnej ideologii. Takie mentalne nastawienie wytwarza istotne problemy związane z niezdolnością do korekty własnych koncepcji, nawet gdy są kwestionowane przez rzeczywistość. W sferze bezpieczeństwa - tam gdzie zagrożone jest życie, zdrowie, mienie i środowisko - ma to fundamentalne znaczenie. Niektórych błędów w sferze bezpieczeństwa nie da się naprawić (Zych, i in., 2016b).

\section{EDUKACJA ANALITYKA JAKO WAŻNY CZYNNIK SPRAWNEGO UCZENIA SIE NA PODSTAWIE DOŚWIADCZEŃ}

Edukacja w sferze bezpieczeństwa poszukuje wciąż nowych dróg, którymi powinno się podążać, aby sprostać stawianym wymaganiom oraz nowym zagrożeniom. Analitycy bezpieczeństwa, szczególnie ci, którzy są blisko działań operacyjnych lub wspomagają decydentów, paradoksalnie są zawieszeni pomiędzy przeszłością i przyszłością. Woluminy wszelkich zasobów informacyjnych rosną w zastraszającym tempie a zarazem mamy głód informacyjny. Świat wokół nich się zmienia, rosną oczekiwania społeczne, zmienia się kultura uczenia się, ciągle doświadczamy nowych zagrożeń. Jak w każdej sferze życia, zmiany są nieuchronne, a uczenie się nie może bazować tylko na tradycyjnej formule podawczej i sekwencyjnej. Adaptacja różnych metod i technik dociekań w sferze bezpieczeństwa stanowi ogromne wyzwanie, zarówno pod względem dydaktycznym, logistycznym, jak i ekonomicznym, szczególnie że stajemy w obliczu barier mentalnych, takich jak bariera percepcji zrutynizowanej. Aby kształcenie analityków bezpieczeństwa zakończyło się sukcesem, w ich przezwyciężenie trzeba włożyć wiele wysiłku, a kadry szkoleniowe powinny być wylęgarnią pomysłów. Jest to jednak wysiłek, który się nam opłaci, bowiem w przeciwnym razie nasze kadry menedżerskie zajmujące się bezpieczeństwem nie będą zdolne do radzenia sobie z zagrożeniami współczesnego świata (Zych i in., 2016a). 
Dążenie do posiadania wiedzy to konieczna, immanentna cecha mentalności analityka bezpieczeństwa. Stale podejmujemy działania zmierzające do zwiększania zasobów wiedzy. Jest to szczególnie istotne w odniesieniu do środowiska naukowego, gdzie dociekania $z$ definicji mają przyczyniać się do zdobywania wiedzy (Zych, 2017, s. 27-28).

\section{Mechanizmy modelu Nonaki i TAKeuChiEgo DOTYCZĄCEGO BUDOWANIA WIEDZY NA PODSTAWIE DOŚWIADCZEŃ}

Człowiek ma wyjątkową zdolność do gromadzenia, przetwarzania, zapisywania i udostępniania doświadczeń w formie wiedzy. Właściwie zarejestrowane doświadczenia i wyekstrahowana z nich wiedza, stanowią wartość samą w sobie, niemniej jednak aby maksymalnie skonkretyzować dalszy wywód, rozpatrywany mechanizm uczenia się na podstawie doświadczeń osadzono w zarządzaniu kryzysowym i wokół tego aspektu prowadzona jest dalsza narracja.

Z każdej sytuacji kryzysowej można się czegoś nauczyć. Każda sytuacja kryzysowa może być znakomitą lekcją. Znaczenia dzielenia się tymi lekcjami nie powinno się ignorować lub nie doceniać. W metodzie tzw. lessons-learned, wyróżnia się cztery ogólne etapy, jakimi są:

- przechwytywanie obserwacji;

- analiza obserwacji i identyfikacja lekcji (do odrobienia);

- transformacja lekcji w projekt działań naprawczych;

- wdrożenie zaprojektowanych działań (dokonanie zmiany w funkcjonowaniu organizacji) i ustanowienie $\mathrm{z}$ tego doświadczenia do ewentualnego zastosowania w przyszłości.

Wymiana obserwacji z uczestnictwa w rożnego rodzaju incydentach czy zdarzeniach ma istotną właściwość. Tak zwane obserwacje są subiektywne i gdy jedne osoby dzielą się nimi z innymi, tworzą się nowe unikatowe skojarzenia, a postrzeganie incydentu przez członków zespołu jest inne, zyskują oni szerszy obraz tego, co się właściwie wydarzyło. 
Rysunek 4.

Główne etapy uczenia się na doświadczeniach

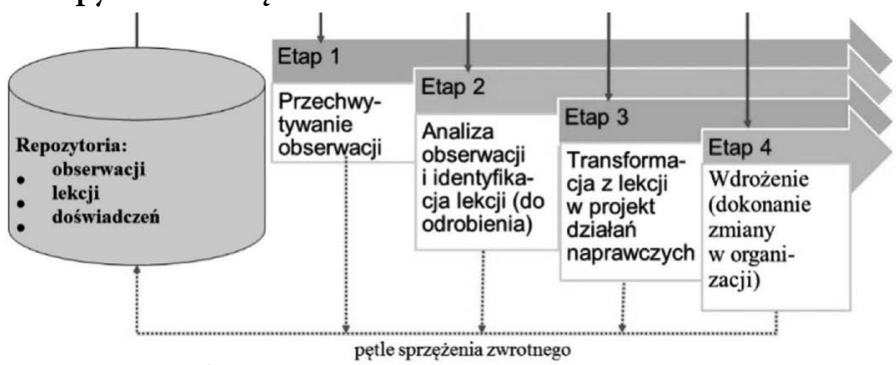

Źródło: opracowanie własne.

\section{Ad. 1) Przechwytywanie obserwacji}

Taka wymiana obserwacji pozwala ją przechwycić i sprowadzić tę obserwację do postaci bardziej sformalizowanej, a po analizie przetworzyć ją w tzw. lekcje do odrobienia, podlegające później wdrożeniu i upowszechnieniu, co jest istotą uczenia się na podstawie doświadczeń.

Rysunek 5.

Główne przedsięwzięcia uczenia się na podstawie doświadczeń w zarządzaniu kryzysowym

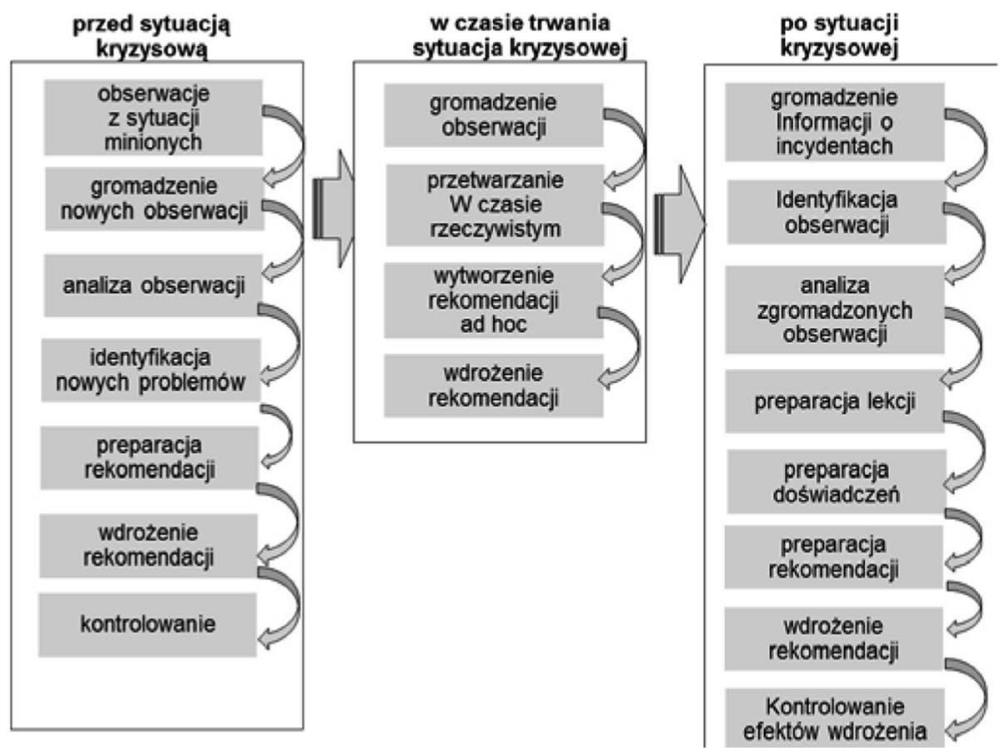

Źródło: opracowanie własne. 
Przechwycenie obserwacji może nastąpić np. w ramach tzw. luźnych wymiany myśli czy też odpraw z personelem. Uczestnicy odpraw mogą uzyskać wspólne zrozumienie problemu z pomocą moderatora przy wykorzystaniu np. metody burzy mózgów. Istnieją dwie alternatywne procedury burzy mózgów. Pierwsza zwana jest techniką mapowania myśli. Moderator sesji przedstawia szablon, a uczestnicy zapisują własne obserwacje i opinie na szablonie wg reguł narzuconych przez prowadzącego odprawę. Druga technika obliguje każdego uczestnika akcji do przedstawienia swoich opinii, a prowadzący lub sekretarz zapisują krótką wersją obserwacji na szablonach. Po zakończeniu zbierania oświadczeń są one umieszczane na wspólnej matrycy z jednoczesnym grupowaniem w tzw. klastry (o tym samym aspekcie akcji). Często realizowane jest to bezpośrednio po zdarzeniu, którego obserwacja dotyczy, gdy wraz z suchymi informacjami przekazuje się emocje. Już na tym etapie lessons-learned wcześniejsze szkolenie i edukacja personelu zarządczego nabierają coraz większego znaczenia.

\section{Ad. 2) Analiza obserwacji i identyfikacja lekcji (do odrobienia)}

Rysunek 6a.

Etapy uczenia się na podstawie doświadczeń w zarządzaniu kryzysowym

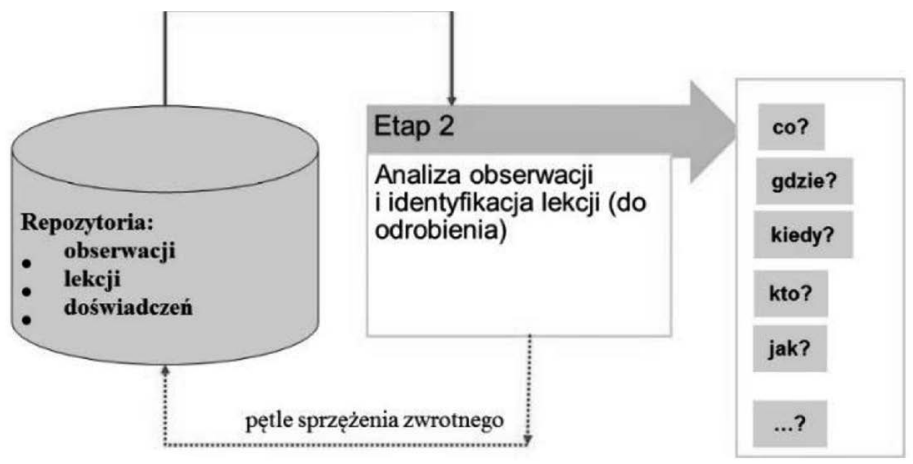

Źródło: opracowanie własne.

W celu uzyskania jak największej wartości informacyjnej z zebranego materiału odprawa wstępna (briefing) lub końcowa są przeprowadzane w dwóch oddzielnych etapach. Jeden etap zorientowany jest na aspekty pozytywne i chętnie w nim aktywnie uczestniczą tzw. użytkownicy końcowi - 
praktycy. Drugi etap koncentruje się na błędach, niedociągnięciach, pomyłkach. Uczestnicy tych odpraw podsumowujących to grupy ludzi, którzy mają wspólne interesy i obawy, a co więcej - są zmotywowani i zainteresowani poszerzaniem swojej wiedzy i zdolności skojarzeniowych. Chętnie dzielą się pomysłami, doświadczeniami, spostrzeżeniami i najlepszymi praktykami. To pozwala uczyć się zarówno z niepowodzeń, jak i najlepszych praktyk z innych organizacji. Rozdrobnione spostrzeżenia składające się na wiedzę są scalane i porządkowane. Wspólne ich omawianie zwiększa prawdopodobieństwo, że osoby zaangażowane w procesy zarządzania kryzysowego mając wspólne zrozumienie problemu, będą dążyły do jego rozwiązania.

\section{Ad. 3) Transformacja lekcji w projekt działań naprawczych}

Rysunek 6b.

Etapy uczenia się na podstawie doświadczeń w zarządzaniu kryzysowym

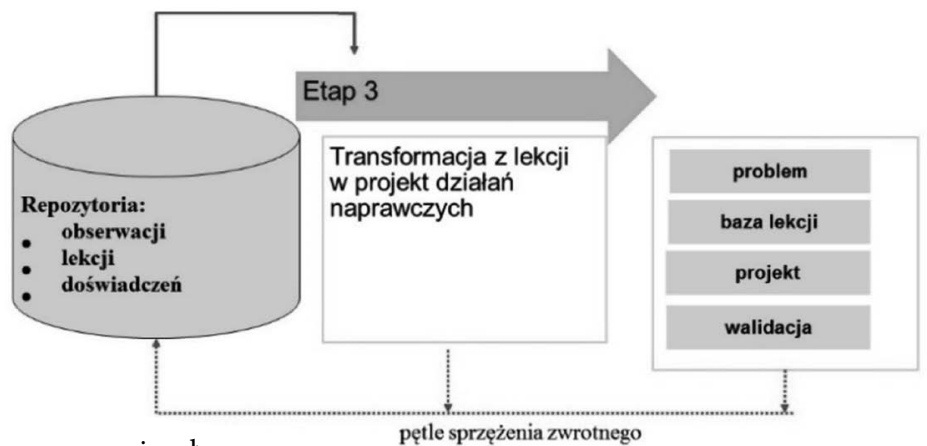

Źródło: opracowanie własne.

W ramach analizy następuje ustalenie okoliczności zdarzenia i udzielenie odpowiedzi na kilka zasadniczych typów pytań: Co się konkretnie wydarzyło? Kiedy się wydarzyło? Dlaczego się wydarzyło? Jak do tego doszło? Efektem tego etapu jest lekcja do odrobienia. Odpowiedzi na zadane wcześniej pytania są podstawą do projektowania działań naprawczych.

Na tym etapie są zazwyczaj formułowane rekomendacje, co zmienić, a czego nie zmieniać. Lekcje już zidentyfikowane można zacząć przekładać na doświadczenia. Aby lekcja stała się doświadczeniem do wykorzystania, konieczne jest wcześniejsze zaprojektowanie i wykonanie działań naprawczych - właśnie na podstawie lekcji do odrobienia. 
Ad. 4) Wdrożenie zaprojektowanych działań (dokonanie zmiany w funkcjonowaniu organizacji) i ustanowienie $z$ tego doświadczenia do zastosowania w przyszłości

To etap realizacji projektu zmian. Po realizacji niezbędne jest sprawdzenie zgodności faktycznych działań z założeniami oraz weryfikacja osiągniętych rezultatów. Pozytywne rozstrzygnięcie tej kwestii daje podstawę do ustanowienia nowego doświadczenia, które można powielać w przyszłości. Powinno nastąpić także upowszechnienie ustanowionego doświadczenia i kontrola, czy upowszechnianie to skutkuje kolejnymi zmianami w organizacji, jeśli było to konieczne. „Naprawa/korekta” stanu niepożądanego następuje właśnie poprzez organizacyjne uczenie się na podstawie doświadczenia. Strukturalizacja wiedzy powstającej w wyniku raportowania i sam proces uczenia się wymagają jednak dalszego omówienia. Proces uczenia zaczyna się, gdy zidentyfikowana lekcja może być przekształcona w prawdziwą nauczkę i będzie miała wpływ na zapobieganie zdarzeniom niepożądanym, przygotowanie, łagodzenie oraz skuteczne i efektywne działania w nowych sytuacjach kryzysowych.

\section{Podsumowanie}

Zarządzanie bezpieczeństwem to proces zorientowany na osiąganie właściwych zmian w zakresie stosowania jego mechanizmów w odniesieniu do nowych wyzwań oraz przyszłych zagrożeń. Chodzi o ujęcie nowych bytów (czyli tego, co istnieje) w planach zarządczych i planach ochrony infrastruktury krytycznej oraz projektowanie nowych procedur reagowania. Jest tu miejsce dla metod opartych na konwersji wiedzy.

Niestety nie każda zmiana ma pożądany charakter. By użyć skrajnego kontrprzykładu, zmianą jest również zapominanie. Precyzując zatem rodzaj zmian, należy stwierdzić, że ważne są zmiany korzystne, czyli te, które niosą poprawę. Nie chodzi o poprawę z jakiegokolwiek aksjologicznego punktu widzenia, dzięki której zarządzający bezpieczeństwem staje się „moralnie” lepszy, lecz o zwiększenie skuteczności i efektywności w procesach analitycznych i podejmowaniu decyzji. Może się też zdarzyć, że następująca zmiana będzie korzystna ze względu na jedno kryterium, a niekorzystna ze względu na inne. Przyjmuje się, że takie zmiany o mieszanych skutkach również 
zasługują na nazwę kształtowania kompetencji, lecz nie są nimi takie zmiany, których konsekwencje są wyłącznie negatywne (Zych, 2013, s. 128-129).

Bezpieczeństwo jako kategoria wieloaspektowa odnosi się do możliwości trwania i rozwoju różnorodnych podmiotów. Obejmuje też rozległy obszar przedmiotowy. Stąd wielość subdyscyplin obejmujących różne sfery badań bezpieczeństwa. Badacz może być zorientowany na różne aspekty rzeczywistości, na rozmaite orientacje poznawcze. Realizmowi, pragmatyzmowi, behawioryzmowi przeciwstawiają się fenomenologia, egzystencjalizm, współczesna cybernetyka czy kognitywizm. Wiedzę możemy czerpać z historii, ale możemy też wytwarzać ją dzięki eksperymentom myślowym, w których antycypujemy stany przyszłe i rozpatrujemy je jako alternatywne scenariusze przyszłości. Brzmi to jak paradoks, ale jeśli będziemy odpowiednio przygotowani mentalnie, faktycznie możemy się uczyć z przyszłości, którą sobie wyobrażamy.

Jednym z subobszarów dotyczących bezpieczeństwa, który wymaga działań naprawczych, jest kształcenie analityków i menedżerów bezpieczeństwa. Ten obszar w Polsce szczególnie wymaga implementacji naukowych i lepszego niż dotychczas uczenia się na podstawie doświadczeń. Konkretnym skutecznym rozwiązaniem jest model konwersji wiedzy Nonaki i Takeuchiego. Nowe ścieżki poznawcze, nowe skojarzenia indukują nowe pomysły. W ramach takich pomysłów proponuje się identyfikować przyszłe byty, stany i procesy mogące się przyczynić do identyfikacji nowych zagrożeń, co do których nie istnieją jeszcze doświadczenia. Aby w obszarze bezpieczeństwa efektywnie i skutecznie wykorzystywać model konwersji wiedzy, konieczne jest mentalne otwarcie się na nowe mechanizmy radzenia sobie z zagrożeniami, w tym odpowiednia edukacja menadżerów i analityków bezpieczeństwa. Jest to szczególnie istotne przy łączeniu doświadczeń historycznych z tymi sprzed wystawienia zagrożeń. Uwaga ta dotyczy zarówno każdego analityka czy menedżera bezpieczeństwa z osobna, jak i całej organizacji, którą współtworzą ci pracownicy.

Eksponując jeszcze raz najważniejszy przekaz wynikający z artykułu, należy stwierdzić, że już sama praca myślowa nad ekstrakcją, a następnie operacjonalizacją wiedzy ukrytej generuje synergię w stawaniu się przez dany podmiot organizacją dojrzałą, odpowiedzialną i względnie bezpiecz- 
ną. Współczesne instytucje zarządzające bezpieczeństwem muszą też być organizacjami permanentnie uczącymi się na podstawie doświadczeń, a model wypracowany przez Nonakę i Takeuchiego bez wątpienia jest godny polecenia.

\section{Literatura}

Apanowicz, J. (2002). Metodologia ogólna, Gdynia: Wydawnictwo Wyższej Szkoły Administracji i Biznesu, s. 24-25, 74, 112. ISBN: 83-910869-9-3.

Apanowicz, J. (2005). Metodologiczne uwarunkowania pracy naukowej. Prace doktorskie, prace habilitacyjne, Warszawa: Difin, s. 67. ISBN: 83-7251-533-6.

Borodako, K. (2009). Foresight $w$ zarzadzaniu strategicznym, Warszawa: Wydawnictwo C.H. Beck, s. 25-29. ISBN: 978-83-255-0816-6.

Encyklopedia Powszechna (1995). Warszawa: Państwowe Wydawnictwo Naukowe, s. 32. ISBN: 83-0111802-4.

Flizikowski, A., Zych, J., Holubowicz, W. (2012). Methodology for gathering data concerning incidents in cyberspace, Military Communications and Information Systems Conference, MCC 20122012, Article number 6387921, s. 230-237, Gdansk, Poland: MCC.

Fórmaniak, C. (2015). Projektowe metody identyfikacji zagrożeń portu morskiego. W: J. Michalak (red.), Oblicza Bezpieczeństwa Narodowego Nr 2(2015) - Wybrane aspekty bezpieczeństwa ekonomicznego, społecznego i militarnego, Gdynia: Akademia Marynarki Wojennej, Wydawnictwo BP, ISBN: 978-83-943934-6-5.

Jamielniak, D., Koźmiński, A.K. (red. nauk.). (2008). Zarządzanie wiedza, podręcznik akademicki, Warszawa: Wydawnictwa Akademickie i Profesjonalne, s. 26. ISBN: 978-83-60501-95-5.

Jóźwiak, I.J., Laskowski, W., Zych, J. (2005). An application of game theory to security and reliability analysis. W: 16th European Safety and Reliability Conference, ESREL 2005; Tri City; Poland, 27 June 2005 through 30 June 2005; according to the SCOPUS database: Code 88581, vol. 1, s. 989-994.

Koernik, S. (2006). Analiza porównawcza Dolnoślaskiej Strategii Innowacji z Regionalnymi Strategiami Innowacji wybranych regionów UE, Metodologia badań porównawczych, s. 16, Wrocław: raport bez numeru ISBN.

Nonaka, I., Takeuchi, H. (2000). Kreowanie wiedzy w organizacji. Jak spółki japońskie dynamizuja procesy innowacyjne, Warszawa: Wydawnictwo Poltex, s. 40. ISBN: 8386890-99-1. 
Watts, J.D. (2003). Unraveling the Mysteries of the Connected Age. W: P.S. Brievik, E. Gordon, Higher Education in the Internet Age. Libraries Creating a Strategic Edge, Westport, Connecticut, London: American Council of Education, Praeger Publishers, s. 9-14. ISBN: 0-275-98194-0.

Zych, J. (2002). Model walki sit obrony powietrznej szczebla taktycznego, Warszawa: Akademia Obrony Narodowej, s. 16-102.

Zych, J. (2011). Metody badawcze w obszarze bezpieczeństwa narodowego. W: P. Sienkiewicz, M. Marszałek, H. Świeboda (red.), Metodologia Bezpieczeństwa Narodowego, Warszawa: Akademia Obrony Narodowej, s. 408-422, ISBN: 978-83-7523$-137-3$.

Zych, J. (2013). Gry decyzyjne dla kształtowania kompetencji kadr menedżerskich zarządzania kryzysowego, Gdynia: Akademia Marynarki Wojennej im. Bohaterów Westerplatte, s. 128-129. ISSN: 1898-3189.

Zych, J. (2017). Teleinformatyka dla bezpieczeństwa, s. 27-28, Poznań: FNCE. ISBN: 978-83-949123-3-8.

Zych, J., Fórmaniak, C. (2016). Metoda studium przypadku do analizy procesów decyzyjnych $w$ zarządzaniu kryzysowym. W: J. Zych (red. nauk.), Studia przypadków w badaniach bezpieczeństwa, Poznań: Wydawnictwo Wyższej Szkoły Bezpieczeństwa, s. 11-20. ISBN: 978-83-65096-44-9.

Zych, J. i in., (2016a). Application "Pomoc" - emergency calls with geo-location. W: Proceedings of the International ISCRAM Conference, 13th International Conference on Information Systems for Crisis Response and Management, ISCRAM 2016; Rio de Janeiro; Brazil; 22 May 2016 through 25 May 2016; according to the SCOPUS database: Code 122171.

Zych, J. i in. (2016b). Scenario-based evaluation of 112 application "Pomoc". W: P. Díaz, N. Bellamine B. Saoud, J. Dugdale, C. Hanachi (red.), Information Systems for Crisis Response and Management in Mediterranean Countries, Series Volume 265, Springer, s. 22-29. ISBN: 978-3-319-47092-4. 